\title{
Temporal variations of Eastern Black Sea aerosol
}

\author{
Balcilar I. ${ }^{1 *}$, Zararsiz A. ${ }^{2}$, Kalayci Y. ${ }^{2}$, Dogan G. ${ }^{3}$ and Tuncel G. ${ }^{1}$ \\ ${ }^{1}$ Department of Environmental Engineering, Middle East Technical University, Ankara, Turkey. \\ ${ }^{2}$ Turkish Atomic Energy Authority, Ankara Nuclear Research and Training Center, Ankara, Turkey. \\ ${ }^{3}$ Department of Environmental Engineering, Akdeniz University, Antalya, Turkey. \\ Received: 24/05/2017, Accepted: 12/10/2017, Available online: 25/01/2018 \\ *to whom all correspondence should be addressed: e-mail: balcilar@metu.edu.tr
}

\section{Abstract}

In this study, chemical composition of coarse (PM 2.5-10) and fine $\left(\mathrm{PM}_{2.5}\right)$ aerosols and their seasonal characteristics was used to investigate factors affecting seasonal variations in concentrations of species. Concentrations of 17 trace elements and $\mathrm{SO}_{4}{ }^{2-}$ were determined in coarse and fine aerosol samples collected at a high altitude $(1115 \mathrm{~m}$ above sea level) site (Torul, $40^{\circ} 32^{\prime} 34^{\prime \prime} \mathrm{N} 39^{\circ} 16^{\prime} 57^{\prime \prime} \mathrm{E}$ ) between March 2011 to November 2012 on the Eastern Black Sea region of Turkey. The samples were analyzed by energy dispersive $x$-ray fluorescence (EDXRF) using an Oxford ED2000 Spectrometer. Measured concentrations varied between approximately $0.40 \pm 0.7 \mathrm{ng} \mathrm{m}^{-3}$ for As and $2070 \pm$ $1270 \mathrm{ng} \mathrm{m}^{-3}$ for $\mathrm{SO}_{4}{ }^{2-}$. Soil-derived elements, $\mathrm{Al}, \mathrm{Si}, \mathrm{K}, \mathrm{Ca}, \mathrm{Ti}$, $\mathrm{V}$ and $\mathrm{Fe}$, had higher concentrations in the coarse fraction as expected. The results indicated that concentrations of elements showed well-defined seasonal variations. Crustal elements showed higher concentration in summer. $\mathrm{Na}$, which is an element generally associated with sea salt had also higher concentrations in summer season, suggesting a strong crustal contribution to $\mathrm{Na}$ concentration at our station. Anthropogenic elements $\mathrm{As}, \mathrm{Zn}, \mathrm{Pb}$ and $\mathrm{Cr}$ had comparable concentrations in both seasons. $\mathrm{Cu}, \mathrm{Ni}$, and $\mathrm{V}$, had higher concentrations in winter season due to sources close to sampling point. Crustal enrichment factors of $\mathrm{Ni}$, $\mathrm{Cu}, \mathrm{Cr}, \mathrm{As}, \mathrm{Pb}, \mathrm{Zn}$ and $\mathrm{SO}_{4}{ }^{2-}$ varied between 12 for $\mathrm{Ni}$ and 800 for $\mathrm{SO}_{4}{ }^{2-}$. Upper atmospheric flow climatology showed that most frequent flow direction was the sector between West and North, indicating the regions between these wind sectors are the potential source regions for the observed levels of species.

Keywords: Trace elements, Aerosol, Temporal variations, EDXRF

\section{Introduction}

Aerosols in the atmosphere originate from both from natural (wind-blown, sea spray, frost fires) and anthropogenic (fuel and biomass burning, industrial processes, traffic emissions) sources (Güllü et al., 2005; Tokgöz, 2013). Global aerosols production estimates suggest that since they interact with solar radiation (IPCC, 2001) and effect micro-meteorological processes (Bhaskar and Mehta, 2010), aerosols may affect Earth's energy balance and hence the climate (Öztürk et al., 2012; Tecer et al., 2012). Therefore, accurate data on the quantity and characteristics of pollutants at the source and receptor sites are required in order to assess perturbations in the biogeochemical cycles of trace elements (Rasmussen, 1998).

Aerosol composition is highly variable in space and time because of the diverse sources (Rostogi and Sarin, 2009). Temporal variations of concentrations depend on several factors including; their sources, transport pattern, and meteorological factors. Since most of these patterns change in time, chemical composition of atmospheric aerosol show short and long term variations (Solomon et al., 1996).

Seasonal variations of particulate matter and factors controlling these variations have been reported in many studies (Carmichael et al., 1996; Güllü et al., 1998; Khillare et al., 2004; Hueglin et al., 2005; Kulshrestha et al., 2009; Cheung et al., 2011; Öztürk et al., 2012; Zhang et al., 2014). These studies have revealed that the seasonal variations of species measured in particulate matter depend on one or more factors of flow frequency from different wind directions (Güllü et al., 1998; Zhang et al., 2014), source type (Hueglin et al., 2005; Kulshrestha et al., 2009), particle scavenging (Öztürk et al., 2012; Zhang et al., 2014) and meteorology (Khillare et al., 2004; Kulshrestha et al., 2009). Several studies showed that the concentration of crustal elements is generally higher in the summer season than those on winter (Güllü et al., 1998; Chakraborty and Gupta, 2010; Alharbi et al., 2015), indicating the enhanced resuspension of soil particles during dry summer months. On the contrary, different seasonal variations in concentrations of crustal elements have been observed depending on the site location and meteorological properties such as wind speed, temperature and humidity (Kulshrestha et al., 2009). Effect of particle scavenging on seasonal variations of species was also investigated (Güllü et al., 1998; Karakaş et al., 2004). Güllü et al., (1998) concluded that the seasonal variations of species were mostly affected by particle scavenging rather than variation in upper atmospheric motions, since variations in the upper atmospheric motions were not large enough to cause 
substantial seasonal variations in concentrations of measured species.

A modeling study conducted by Pervin (1991), has shown that the most of the $\mathrm{SO}_{4}{ }^{2-}$ concentration at the Eastern Black Sea region of Turkey was originating from distant sources, and showing that the contribution of Turkey was very small. However, studies conducted in the Black Sea region of Turkey are scarce (Hacisalihoğlu et al., 1992; Karakaş et al., 2004; Doğan et al., 2010; Tecer et al., 2012). In this study size-distributed aerosol samples, ( $\left.\mathrm{PM}_{2.5-10}\right)$ and $\mathrm{PM}_{2.5}$ ), were collected at a high altitude rural station located Eastern part of Black Sea region of Turkey. The station was established at a relatively pristine site, where there are no significant local sources, to investigate the factors affecting seasonal variations in concentrations of elements. This paper presents seasonal patterns in Eastern Black Sea aerosol.

\section{Methodology}

The sampling station was located at a log storage area of the Ministry of Forestry, which was located at approximately $5 \mathrm{~km}$ to southwest of the Torul village at the Eastern Black Sea coast of Turkey $\left(40^{\circ} 32^{\prime} 34^{\prime \prime} \mathrm{N}\right.$, $\left.39^{\circ} 16^{\prime} 57^{\prime \prime} E\right)$. Sampling station was surrounded by barren land. Altitude of the station was $1115 \mathrm{~m}$ above sea level. The station was approximately $70 \mathrm{~km}$ from the coastline and shown in Figure 1. Sampling was performed between March 2011 and December 2012. The sample collection period was $24 \mathrm{~h}$ for all collected samples and sampling were interrupted only to change filters. In total, 270 daily coarse and fine aerosol samples were collected.
Coarse $\left(\mathrm{PM}_{2.5-10}\right)$ and fine $\left(\mathrm{PM}_{2.5}\right)$ aerosol samples were collected on polycarbonate (Nuclepore) filters using Gent Stacked Filter Unit (SFU) (Hopke et al., 1997). The SFU was operated at a fixed flow rate of $16.7 / \mathrm{min}^{-1}$. The initial and second filters were $47 \mathrm{~mm}$ in diameter with pore sizes of 8 and $0.4 \mu \mathrm{m}$, respectively. Coarse and fine fractions of the aerosol were collected separately on these filters. The flow through filters will result in the collection of the particles with diameters larger than $2.2 \mu \mathrm{m}$ on the initial filter (coarse fraction). Those with diameters smaller than 2.2 $\mu \mathrm{m}$ pass through the initial filter and were held on the backup filter (fine fraction).

Before and after sampling, coarse and fine filters were desiccated in a constant humidity chamber for $24 \mathrm{~h}$ to reach a constant humidity and weighed using microbalance (Sartorius, Model MC-5). Mass concentrations of fine and coarse particles were determined gravimetrically from the difference in filter weights before and after sampling.

Samples were analyzed using an energy dispersive X-Ray Spectrometer (EDXRF) (Oxford, model ED-2000) for trace elements including $\mathrm{Na}, \mathrm{Mg}, \mathrm{Al}, \mathrm{Si}, \mathrm{S}, \mathrm{K}, \mathrm{Ca}, \mathrm{Ti}, \mathrm{V}, \mathrm{Cr}, \mathrm{Mn}, \mathrm{Fe}$, $\mathrm{Ni}, \mathrm{Cu}, \mathrm{Zn}, \mathrm{As}, \mathrm{Ba}$ and $\mathrm{Pb}$ at Sarayköy research center of the Turkish Atomic Energy Agency (TAEK). An Ag anode X-ray tube with maximum current of $1000 \mu \mathrm{A}$ and with maximum voltage of $50 \mathrm{kV}$ was used as a source of excitation. The EDXRF was calibrated with spiked synthetic standards and accuracy of results were tested by running NIST SRM 2783 (Air Particulate Matter on Filter Media). More detailed description of the analytical system and blank levels are given elsewhere in Balcilar et al., (2014).

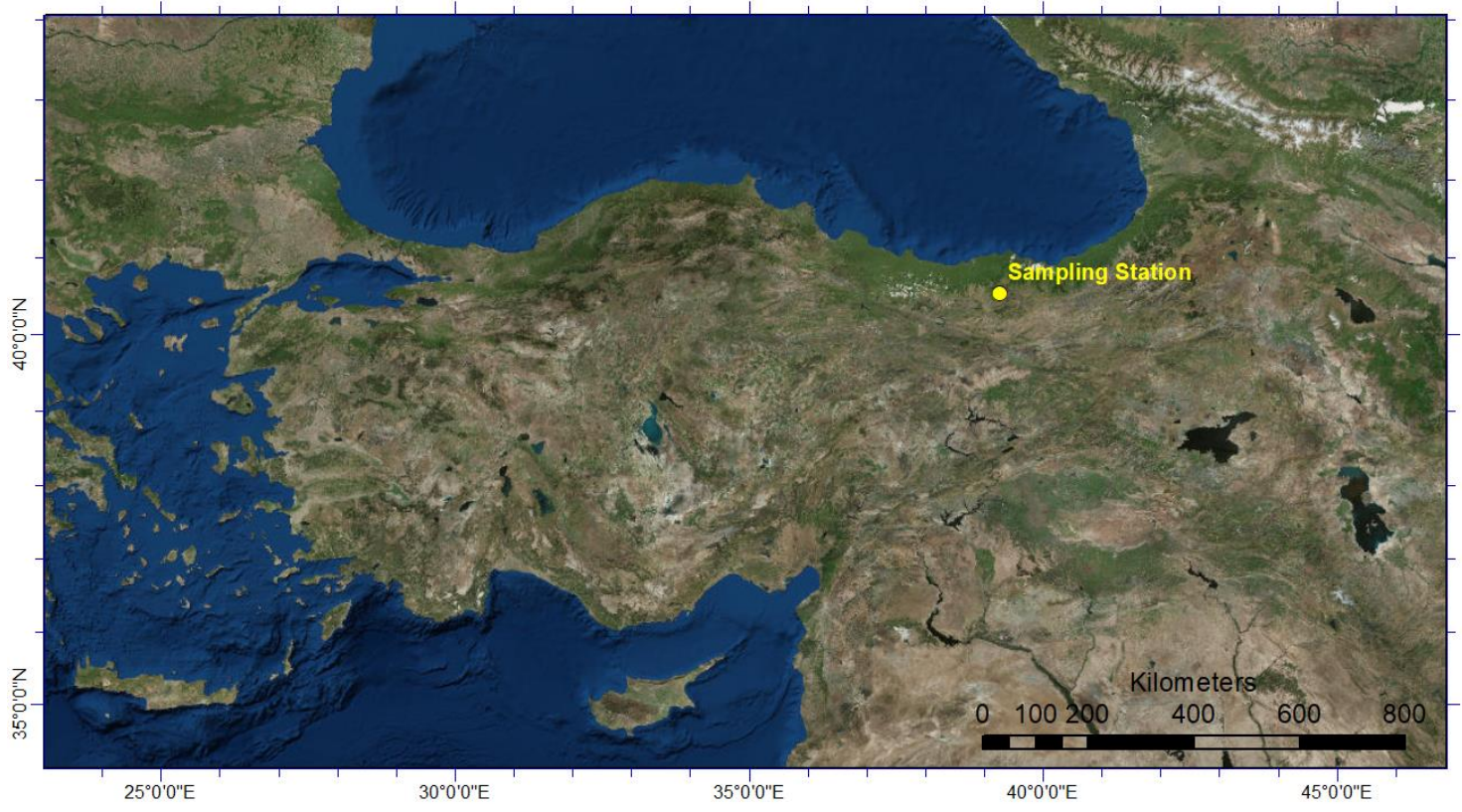

Figure 1. Location of the sampling location

\section{Results and discussions}

Median values of measured species in the coarse and fine fraction aerosols are plotted in Figure 2. Concentrations in the data set varied between $0.40 \pm 0.7 \mathrm{ng} \mathrm{m}^{-3}$ for As and $2070 \pm 1270 \mathrm{ng} \mathrm{m}^{-3}$ for $\mathrm{SO}_{4}{ }^{2-}$. Karakaş, (1999) reported background values at central Black Sea region of Turkey for As and $\mathrm{SO}_{4}{ }^{2-}$ as $1.6 \pm 1.6 \mathrm{ng} \mathrm{m}^{-3}$ and $4900 \pm 2900 \mathrm{ng} \mathrm{m}^{-3}$, respectively. Concentration of $\mathrm{Na}$, a good marker element for sea salt, was fairly low compared to $\mathrm{Na}$ concentrations reported in Turkish coastal studies. Concentration of $\mathrm{Na}$ is 
highly dependent on the distance between sampling station and coastline, which was $70 \mathrm{~km}$ in our case. Its concentration was higher in the coarse fraction. Although most of the coarse sea-salt particles deposit during $70 \mathrm{~km}$ transport from coast to our station, non-sea-salt Na comes from soil particles, which are also coarse. Therefore, occurrence of $\mathrm{Na}$ in coarse fraction is not surprising.

Concentrations of soil-derived elements, including $\mathrm{Al}, \mathrm{Si}, \mathrm{K}$, $\mathrm{Ca}, \mathrm{Ti}, \mathrm{V}$ and Fe were higher in the coarse fraction, because soil particles have a mass median diameter between 3.0 $3.5 \mu \mathrm{m}$ (Kuloglu and Tuncel, 2005). Coarse-to-fine ratios of these elements varied between 1.2 for $\mathrm{K}$ and 3.1 for $\mathrm{Ca}$.

Concentrations of elements with mixed natural and anthropogenic sources (residual fuel combustion, metal processing), such as, $\mathrm{Ti}, \mathrm{V}, \mathrm{Cr}, \mathrm{Mn}$ and $\mathrm{Ni}$ had comparable concentrations in coarse and fine fraction particles. Since parts of their concentrations are due to presence of coarse soil particles, this is an expected pattern for these elements.

Pollution-derived elements measured in this work, including $\mathrm{SO}_{4}{ }^{2-}, \mathrm{Cu}, \mathrm{Zn}, \mathrm{As}$ and $\mathrm{Pb}$ had higher concentration in fine fraction. Their coarse-to-fine median ratios varied between 0.2 for $\mathrm{SO}_{4}{ }^{2-}$ ion and unity for As. Sulfate ion had smallest coarse-to-fine ratio, which is followed by $\mathrm{Pb}(\mathrm{C} / \mathrm{F}$ ratio is 0.5 ). Coarse to fine ratios of elements is a reflection of their size distribution in the atmosphere. Lead and $\mathrm{SO}_{4}{ }^{2-}$ were reported to have smallest mass median diameter $(0.7$ $\mu \mathrm{m}$ for $\mathrm{Pb}$ and $0.5 \mu \mathrm{m}$ for $\mathrm{SO}_{4}{ }^{2-}$ ) in an impactor study performed at the Eastern Mediterranean (Kuloglu and Tuncel, 2005).

Summer and winter season median values of measured species are shown in Figure 3. Summer, in this study, is the period between May and October and winter is the remainder of the year. This division is based on the rainfall amount, because rainfall is one of the most important parameters affecting seasonal variation in concentration of elements (Güllü et al., 1998; 2005). In the Black Sea region, approximately $80 \%$ and $20 \%$ of the precipitation occurs in winter and summer months, respectively.

Summer-to-winter median concentration ratios of elements varied between 1.92 for $\mathrm{Al}$ and 0.08 for $\mathrm{V}$. Elements with the highest summer-to-winter ratio were crustal elements and $\mathrm{SO}_{4}{ }^{2-}$. Higher concentrations of crustal elements during summer, is due to easier resuspension of soil particles during the dry summer season. Since soil is damp or ice covered in winter, resuspension of local soil is less likely. This scenario results in higher concentrations of soil-related elements in summer. Concentration of $\mathrm{SO}_{4}{ }^{2-}$ was also higher in summer owing to higher solar flux, which leads to faster gas-phase oxidation of $\mathrm{SO}_{2}$.

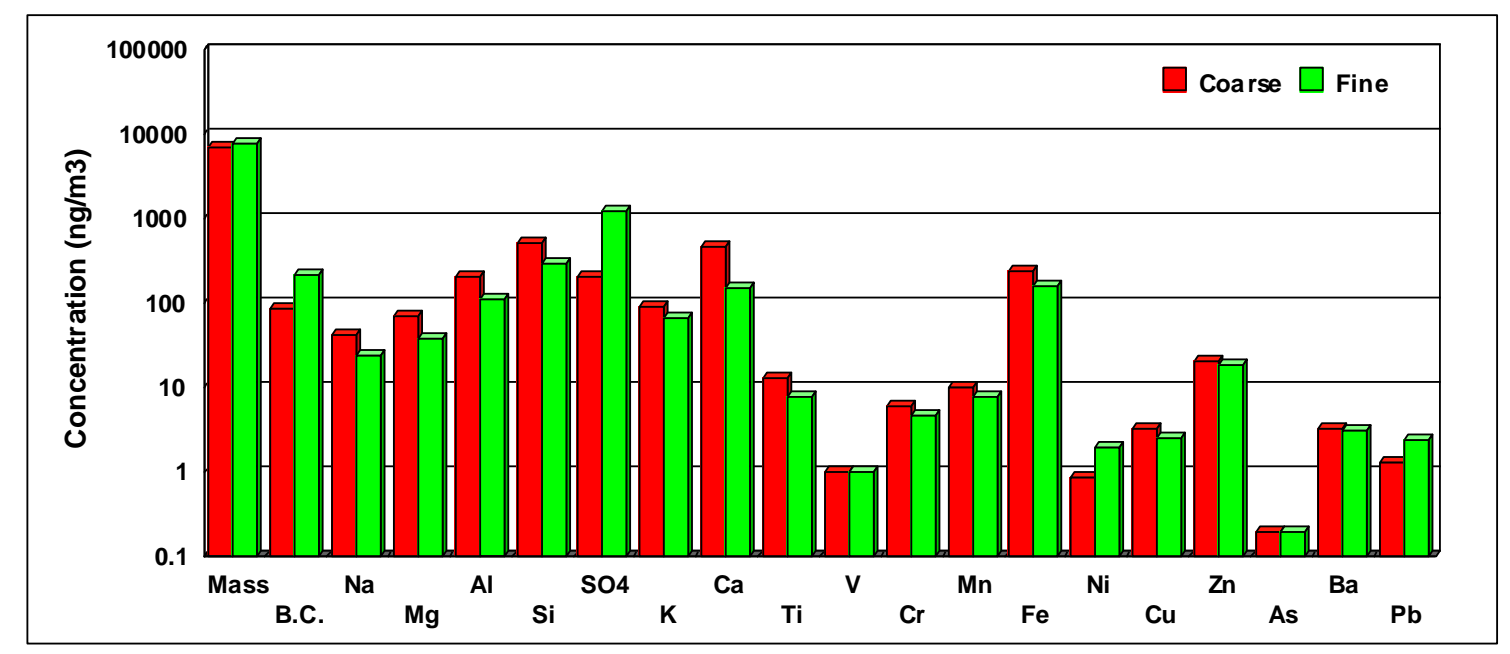

Figure 2. Median values of measured species in the Eastern Black Sea

Sodium is frequently used as marker element to quantify sea salt contribution to aerosol mass. Since more active storm activity over the sea generates higher quantities of sea salt during the winter season, higher concentrations of sea-salt elements are expected in the winter season. However, summer-to-winter median concentration ratio for $\mathrm{Na}$, in this study, was 1.6 , which is comparable to corresponding ratios observed in crustal elements. Higher $\mathrm{Na}$ concentrations during summer season are probably due to approximately $70 \mathrm{~km}$ distance between the coastline and our station. Since sea salt particles are coarse they are quickly scavenged from atmosphere within few kms from coastline and crustal contribution start to dominate $\mathrm{Na}$ concentrations at distances far from the coastline. A crude calculation using Al-to-Na ratio in Mason's (1966) crustal compilation, $\mathrm{Al}$ and $\mathrm{Na}$ concentrations in our samples demonstrated that, on the average, more than $90 \%$ of observed $\mathrm{Na}$ concentration at Torul station could be accounted for by crustal aerosol, which explains higher concentrations of $\mathrm{Na}$ recorded in summer season.

Elements with mixed origin, like $\mathrm{K}, \mathrm{Ti}$ and anthropogenic elements, such as $\mathrm{As}, \mathrm{Zn}, \mathrm{Pb}$ and $\mathrm{Cr}$ had comparable concentration is summer and winter seasons. This pattern is not unique and reported in many studies around the Black Sea and Eastern Mediterranean (Güllü et al., 2005) and Black Sea (Karakas et al., 2004; Tokgöz and Tuncel, 2015) basins. The only exceptions to this general pattern were observed in concentrations of $\mathrm{Cu}, \mathrm{Ni}$, and $\mathrm{V}$, which have higher concentrations in winter season. This unexpected pattern could be an artifact for $\mathrm{V}$ because it was measured in only few samples during summer period, 
but the pattern was real for $\mathrm{Cu}$ and $\mathrm{Ni}$. Particle scavenging by rain is probably the most important factor affecting seasonal variations in concentrations of elements. Particles are scavenged from atmosphere more effectively in winter with frequent rain events during their transport from their source regions to Eastern Black Sea, which results in higher concentrations of elements in summer. Elements that have nearby sources are not affected from scavenging as much and can have relatively high concentrations in winter season as well. Thus, higher concentrations of $\mathrm{Ni}$ and $\mathrm{Cu}$ in winter can be attributed to their local sources. Smelters at Samsun, Murgul (Artvin), Georgia and Ukraine (Dzubay and Stevens, 1984) may be the nearby sources that can affect seasonal variation in concentrations of these elements. Rain scavenging was shown to be the main reason determining seasonal variation in concentrations of elements at Eastern Mediterranean as well (Karakaş et al., 2004; Doğan et al., 2008; Koçak et al., 2007).

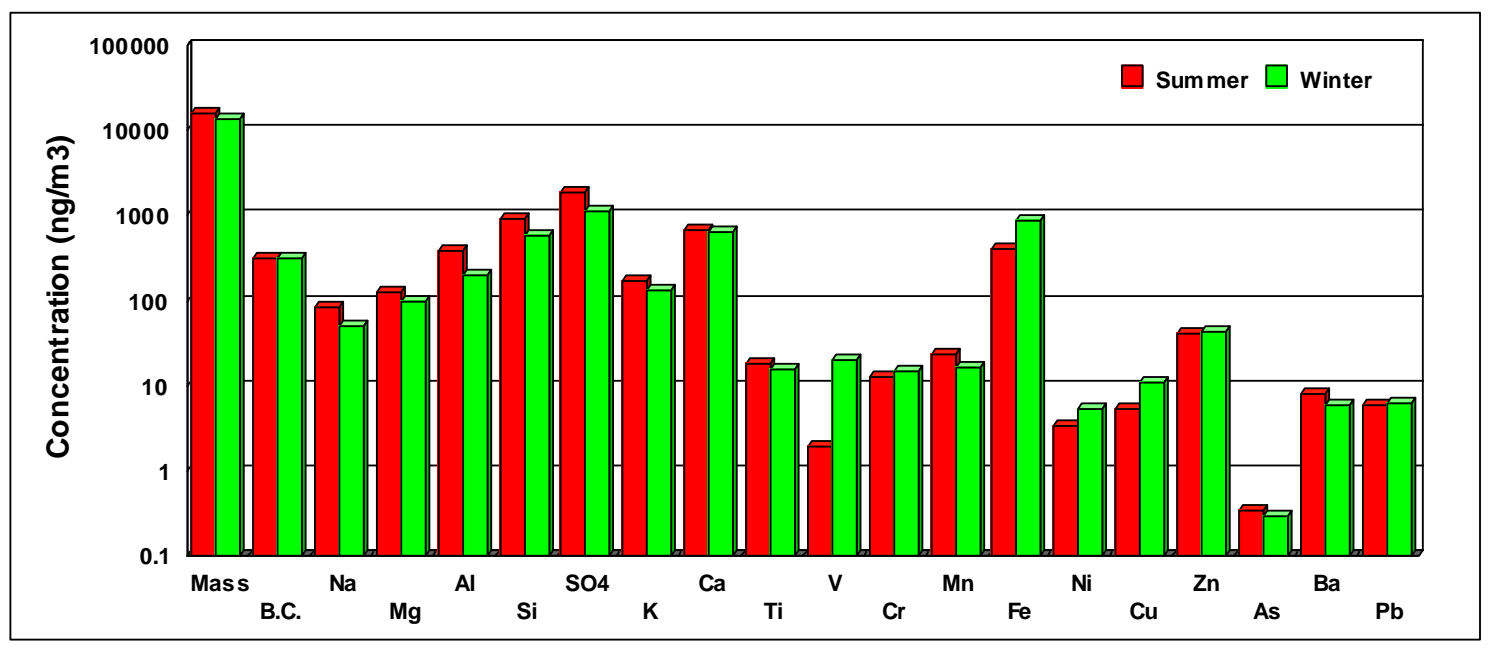

Figure 3. Summer and winter season median values of species

\subsection{Crustal enrichment factors of elements}

Chemical composition of the aerosols in the atmosphere is controlled by mixing of various natural and anthropogenic components and the extent to which the mixing occurs will vary both in space and time. Enrichment factors (EF), which provide qualitative information on the crustal and noncrustal components in aerosol population (Zoller et al., 1974) are generally calculated relative to soil composition as soil is the most common component in aerosol population, EF can also be calculated relative to any source for which a reliable reference element is available.

Crustal Enrichment factor (EFc) of an element can be calculated using the following relation (Eqn. 1):

$$
\text { EFC }=\frac{\left(C_{x} / C_{A l}\right)_{\text {sample }}}{\left(C_{x} / C_{A l}\right)_{\text {soil }}}
$$

Where $\left(C_{x} / C_{A l}\right)_{\text {sample }}$ is the ratio of the concentration of the test element $\left(C_{x}\right)$ to that of $\mathrm{Al}$ in the sample. $\left(C_{x} / C_{A l}\right)_{\text {soil }}$ is the same ratio in soil. Aluminum is a generally used as crustal reference element, because its main source in aerosol is the crustal material (except for very small areas around Al plants) and it can be measured reliably using variety of analytical techniques. Other crustal markers, such as Fe, Sc, rare earths etc can also be used as crustal reference element. However, they are not as widely used either because they may have non-crustal sources (like Fe) or their measurements in atmospheric aerosol are not as easy as measurement of $\mathrm{Al}$ (like Sc, rare earth element). Global compilations of soil composition are used to calculate $\left(C_{x} / C_{A l}\right)_{\text {soil }}$ in the relation. The $\mathrm{EF}$ values calculated in this work are based on the data given for the mean abundances of elements in the Earth's crust by Mason (1966). Since composition of local soil around the sampling point may be different from that of Mason's (1966) compilation, elements with EFc values < 10 are not considered as enriched. The EFc value of 1.0 (or <10) indicates that source of the element is exclusively crustal material. EFc values $>10$ indicate enrichment and noncrustal source for the test element.

Enrichment factor of elements in, summer and winter seasons are given in Figure 4. Elements $\mathrm{Fe}, \mathrm{Na}, \mathrm{Ti}, \mathrm{Mg}, \mathrm{K}, \mathrm{V}$, $\mathrm{Ba}, \mathrm{Ca}$ and $\mathrm{Mn}$ had enrichment factors $<10$ in both summer and winter seasons, indicating that there is no source other than crustal material for these elements.

$\mathrm{Ni}, \mathrm{Cu}, \mathrm{Cr}, \mathrm{As}, \mathrm{Pb}, \mathrm{Zn}$ and $\mathrm{SO}_{4}{ }^{2-}$ had enrichment factors between 12 for $\mathrm{Ni}$ and 800 for $\mathrm{SO}_{4}{ }^{2-}$. These are well documented anthropogenic elements and their enrichments are not surprising (Ho et al, 2003; Kim et al., 2009; Tecer et al., 2012). In order to distinguish the natural and anthropogenic sources of the enriched elements, enrichment factor (EF) diagrams which are the log-log plots of crustal enrichment factors of elements vs. Al concentrations were generated. The EFc - Al plots of selected enriched elements are given Figure 5.

The EFc of crustal elements does not change with changes in $\mathrm{Al}$ concentrations resulting in a horizontal line in the $\mathrm{EF}$ diagram. The EF diagram of $\mathrm{Ti}$ is given in Figure 5 as an example. 
Among those moderately and highly enriched elements namely, $\mathrm{Cr}$ and $\mathrm{SO}_{4}{ }^{2-}$ also given in Figure 5, indicating these elements have sources other than crustal dust. The EFc values of these elements show an inverse relation with $\mathrm{Al}$ concentration. EFc values of these elements decrease with increasing $\mathrm{Al}$ concentration.

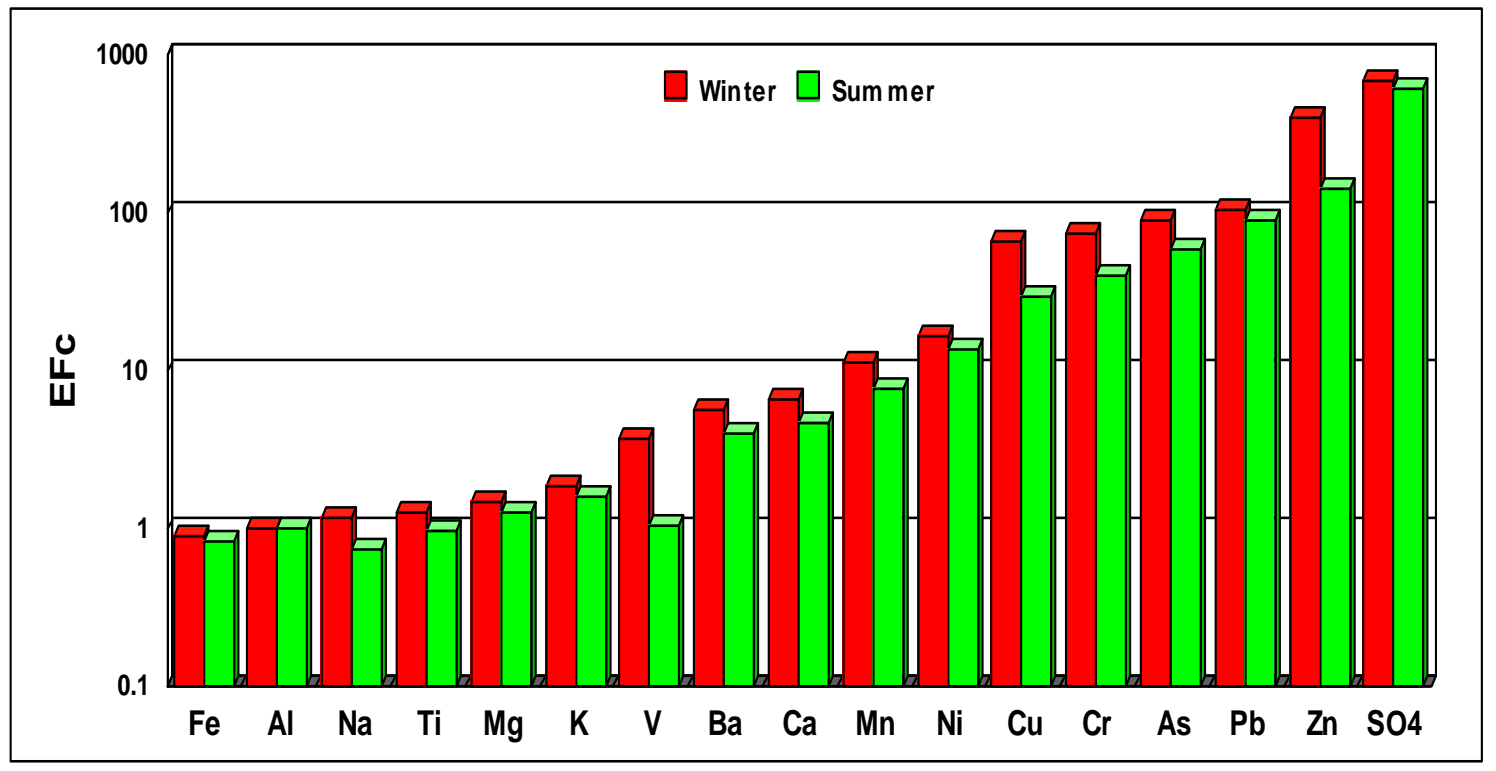

Figure 4. Seasonal crustal enrichment factors

\subsection{Flow climatology}

In order to assess long range transport of pollutants to the Eastern Black Sea atmosphere, both emission strength and frequency of flow from source regions are important for
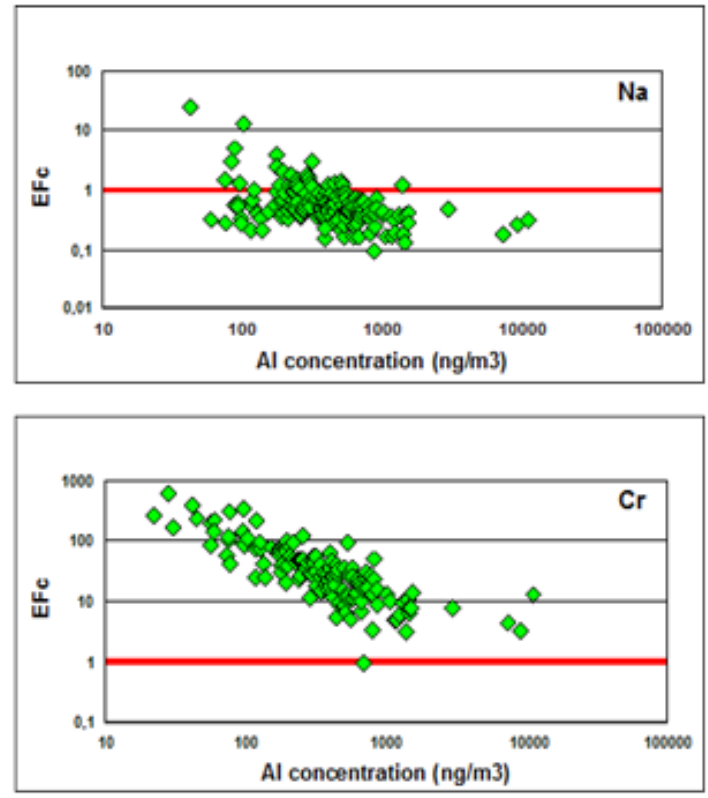

the contribution of sources to measured concentrations of elements at the receptor. Therefore, it is essential to know flow frequencies at different wind sectors, which is also called flow climatology, to apportion sources at the sampling location.
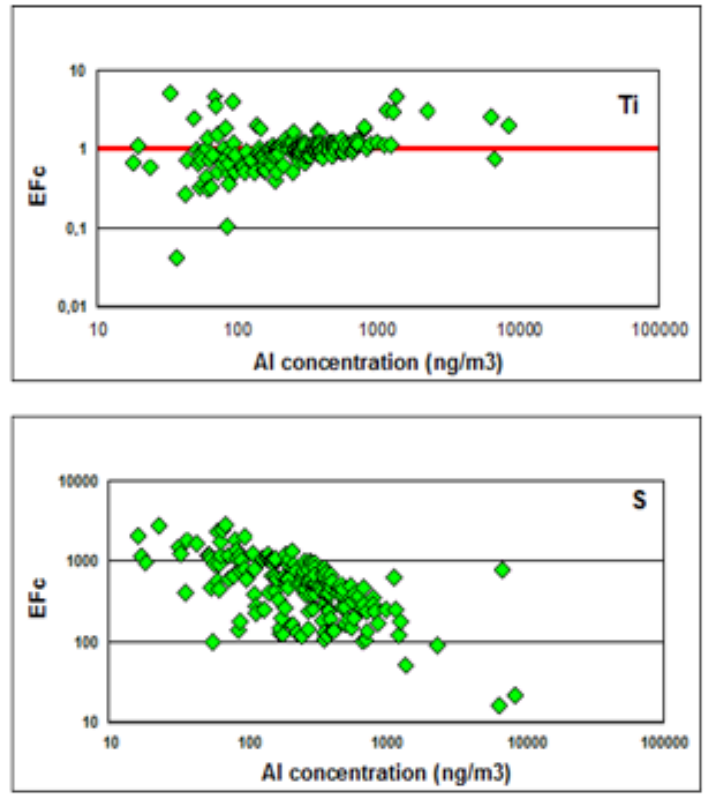

Figure 5. EFc versus Al concentrations of selected elements

In this study, the HYbrid Single-Particle Lagrangian Integrated Trajectory (HYSPLIT) Version 4 (Stein et al., 2015) model was used to determine flow frequencies at different wind sectors. Five-day back trajectories starting from the sampling station at 19:00 UTC at 3 different altitudes, namely 100, 500 and 1500 meter were calculated for the years 2011 and 2012. Reanalysis meteorological data archive of the NOAA was used as input data for back trajectory calculations. Isentropic vertical motion method type was selected in the model calculation. Five-day long back trajectories were long enough to cover the major source regions that thought to be affecting Eastern Black 
Sea atmosphere and they were not long enough to cause unreasonably high uncertainties. The trajectories were divided into hourly segments. As the trajectories were 5 day long, each trajectory was consisted of 120 segments. For each arrival heights 261 back trajectories were calculated. Calculated segments for 100, 500, 1500 meter were approximately 30000 and for combination of these 3 arrival height were approximately 95000.

The study domain was dived into 8 directional sectors as follows: North (N), North East (NE), East (E), South East (SE), South (S), South West (SW), West (W) and North West (NW). In order to understand flow pattern, each 1-hour segment obtained from back trajectories was assigned to a wind sector and the number of segments in each of the eight wind sectors were counted by using GIS software. The frequencies of airflow from each sector are presented in Figure 6.

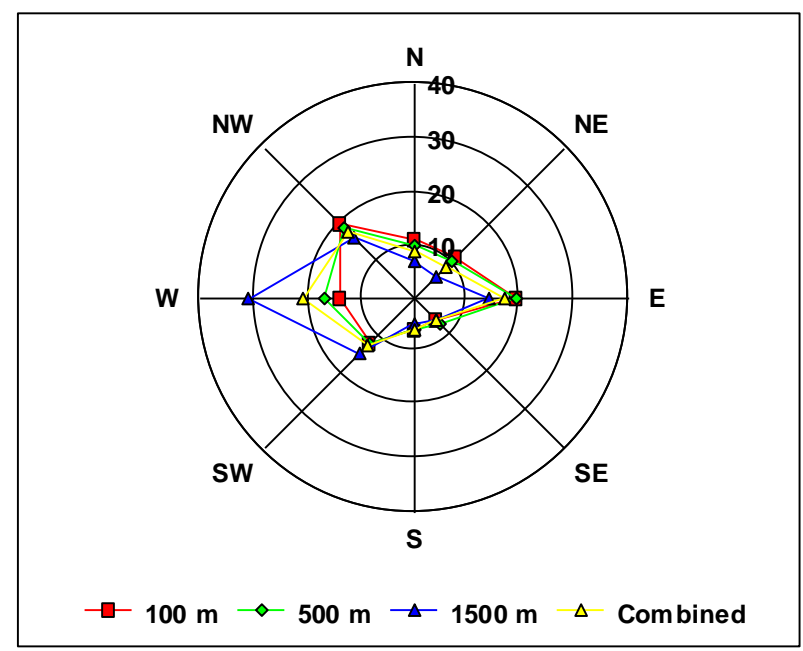

Figure 6. Annual frequency of flow from each wind sector for 100, 500, $1500 \mathrm{~m}$ arrival height back trajectories and combined back trajectories (Numbers in the figure are the percent contribution of each sector)

The general pattern that is observed is higher contribution of W, NW and E sectors and particularly low contribution of SE and S sectors. Total contribution of W, NW and $E$ is $56 \%$. Such flow frequencies from these wind sectors reveal that countries such as Ukraine, Georgia and Russia are important source regions for the observed concentrations of pollutants (Tokgöz, 2013; Tokgöz et al., 2012; Hacısalihoğlu et al., 1992; Dzubay and Stevens, 1984).

\section{Conclusions}

Daily coarse ( $\left.\mathrm{PM}_{2.5-10}\right)$ and fine ( $\left.\mathrm{PM}_{2.5}\right)$ aerosol samples were collected between 2011 and 2012 at the Eastern Black Sea coast of Turkey, using a stack filter unit. Collected samples were analyzed for 17 elements, including $\mathrm{Na}, \mathrm{Mg}$, $\mathrm{Al}, \mathrm{Si}, \mathrm{K}, \mathrm{Ca}, \mathrm{Ti}, \mathrm{V}, \mathrm{Cr}, \mathrm{Mn}, \mathrm{Fe}, \mathrm{Ni}, \mathrm{Cu}, \mathrm{Zn}, \mathrm{As}, \mathrm{Ba}, \mathrm{Pb}$ and $\mathrm{SO}_{4}{ }^{2-}$. Most of the crustal elements occurred in coarse and most of the anthropogenic elements occurred in the fine fraction. Coarse-to-fine ratios of elements are related to their size distributions. Lead and $\mathrm{SO}_{4}{ }^{2-}$ are the species with the lowest $\mathrm{C} / \mathrm{F}$ ratio and they are also the parameters with the smallest mass median diameters.
Concentrations of crustal elements are higher in summer season due to more effective resuspension of soil particles during dry summer months. Concentrations of anthropogenic elements were comparable in both seasons. Only concentrations of $\mathrm{Cu}$ and $\mathrm{Ni}$ were lower in summer season, which was explained by the presence particles from local sources.

Crustal enrichment factors of elements were $<10$ for soilrelated elements and varied between 12 and 800 for elements with anthropogenic origin.

Upper atmospheric flow climatology showed that most frequent flow direction was the sector between $\mathrm{W}$ and $\mathrm{N}$. Contribution of southern sectors to total flow was negligibly small.

\section{Acknowledgement}

This work was supported by the Scientific and Technological Research Council of Turkey (TUBITAK) Grant No 108Y306. We would like to thank General Directory of Forestry for allowing us to use their facilities for sampling.

\section{References}

Alharbi B., Shareef M.M. and Husain T. (2015), Study of chemical characteristics of particulate matter concentrations in Riyadh, Saudi Arabia, Atmospheric Pollution Research, 6(1), 88-98.

Balcilar I., Zararsız A., Kalaycı Y., Doğan G., and Tuncel G. (2014), Chemical composition of eastern black sea aerosolpreliminary results, Science of the Total Environment, 488-489(1), 422-428.

Bhaskar B.V. and Mehta V.M. (2010), Atmospheric particulate pollutants and their relationship with meteorology in Ahmedabad, Aerosol Air Quality Research, 10(4), 301-315.

Carmichael G.R., Zhang Y., Chen L.L., Hong M.S. and Ueda H. (1996), Seasonal variation of aerosol composition at Cheju Island, Korea, Atmospheric Environment, 30(13), 2407-2416.

Chakraborty A. and Gupta T. (2010), Chemical characterization and source apportionment of submicron (PM1) aerosol in Kanpur region, India, Aerosol and Air Quality Research, 10(5), 433-445.

Cheung K., Daher N., Kam W., Shafer M.M., Ning Z., Schauer J.J. and Sioutas C. (2011), Spatial and temporal variation of chemical composition and mass closure of ambient coarse particulate matter (PM 10-2.5) in the Los Angeles area, Atmospheric Environment, 45(16), 2651-2662.

Doğan G., Gülen G., Karakaş D. and Tuncel G. (2010), Comparison of source regions affecting $\mathrm{SO}_{4}{ }^{2-}$ and $\mathrm{NO}_{3}{ }^{-}$concentrations at the Eastern Mediterranean and Black Sea atmospheres, Current Analytical Chemistry, 6, 66-71.

Doğan G., Karakas D., Tuncel G. and Genç D. (2008), Determination of long range potential source regions of anthropogenic substances in the Black Sea coast of Turkey, Geophysical Research Abstracts, 10, EGU2008-A-06383.

Dzubay T.G., Stevens R.K. and Haagenson P.L. (1984), Composition and origins of aerosol at a forested mountain in Soviet Georgia, Environmental Science and Technology, 18, 873-878.

Güllü G., Olmez I., Aygu S. and Tuncel G. (1998), Atmospheric trace element concentrations over the Eastern Mediterranean Sea: factors affecting temporal variability, Journal of Geophysical Research, 103, 21943-21954. 
Güllü G., Doğan G. and Tuncel G. (2005), Atmospheric trace element and major ion concentrations over the eastern Mediterranean Sea: Identification of anthropogenic source regions, Atmospheric Environment, 39, 6376-6387.

Hacısalihoğlu G., Eliyakut F., Ölmez I., Balkas T.I. and Tuncel G. (1992), Chemical composition of particles in the Black Sea atmosphere, Atmospheric Environment, 26A, 3207-3218.

Ho K.F., Lee S.C., Chan C.K., Jimmy C.Y., Chow J.C., Yao X.H. (2003), Characterization of chemical species in PM 2.5 and PM 10 aerosols in Hong Kong, Atmospheric Environment, 37(1), 31-39.

Hopke P.K., Xie Y., Raunema T., Biegalski S., Landsberger S., Maenhaut W., Artaxo P. and Cohen D. (1997), Characterization of the Gent Stacked Filter Unit PM10 Sampler, Aerosol Science and Technology, 27, 726-735.

Hueglin C., Gehrig R., Baltensperger U., Gysel M., Monn C. and Vonmont H. (2005), Chemical characterisation of PM2. 5, PM10 and coarse particles at urban, near-city and rural sites in Switzerland, Atmospheric Environment, 39(4), 637-651.

IPCC, Climate Change 2001. (2001), Intergovernmental Panel on Climate Change, Cambridge University Press, London.

Karakaş D. (1999), Determination of the European contribution on the aerosol composition in the Black Sea and investigation of transport mechanisms, Ph.D. Thesis, Middle East Technical University.

Karakaş D., Olmez I., Tosun S. and Tuncel G. (2004), Trace and major element compositions of Black Sea aerosol, Journal of Radioanalytical and Nuclear Chemistry, 259(1), 187-192.

Khillare P.S., Balachandran S. and Meena B.R. (2004), Spatial and temporal variation of heavy metals in atmospheric aerosol of Delhi, Environmental Monitoring and Assessment, 90(1), 1-21.

Kim N.K., Park H.J. and Kim Y.P. (2009), Chemical composition change in TSP due to dust storm at Gosan, Korea: do the concentrations of anthropogenic species increase due to dust storm?, Water, air, and soil pollution, 204(1-4), 165-175.

Kuloglu E. and Tuncel G. (2005), Size distribution of trace elements and major ions in the eastern Mediterranean atmosphere, Water Air Soil Pollution, 167, 221-241.

Kulshrestha A., Satsangi P.G., Masih J. and Taneja A. (2009), Metal concentration of PM 2.5 and PM 10 particles and seasonal variations in urban and rural environment of Agra, India, Science of the Total Environment, 407(24), 6196-6204.

Koçak M., Mihalopoulos N. and Kubilay N. (2007), Chemical composition of the fine and coarse fraction of aerosols in the northeastern Mediterranean, Atmospheric Environment, 41(34), 7351-7368.

Mason B. (1966), Principles of Geochemistry, John Wiley, New York.

Öztürk F., Zararsız A., Dutkiewicz V.A., Husain L., Hopke P.K. and Tuncel G. (2012), Temporal Variations and Sources of Eastern Mediterranean Aerosols Based on a 9-Year Observation, Atmospheric Environment, 61, 463-475.

Pervan T. (1991), Application of a Regional Air Pollution Transport Model, Middle East Technical University.

Rasmussen P.E. (1998), Long-range atmospheric transport of trace metals: the need for geoscience perspectives, Environmental Geology, 33(2-3), 96-108.

Rastogi N. and Sarin M.M. (2009), Quantitative chemical composition and characteristics of aerosols over western India: One-year record of temporal variability, Atmospheric Environment, 43(22), 3481-3488.
Solomon S., Portmann R.W., Garcia R.R., Thomason L.W., Poole L.R. and McCormick M.P. (1996), The role of aerosol variations in anthropogenic ozone depletion at northern midlatitudes, Journal of Geophysical Research: Atmospheres, 101(D3), 6713-6727.

Stein A.F., Draxler R.R, Rolph G.D., Stunder B.J.B., Cohen M.D. and Ngan F. (2015), NOAA's HYSPLIT atmospheric transport and dispersion modeling system, Bulletin of the American Meteorological Society, 96, 2059-2077.

Tecer L.K., Tuncel G., Karaca F., Alagha O., Süren P., Zararsiz A. and Kirmaz R. (2012), Metallic composition and source apportionment of fine and coarse particles using positive matrix factorization in the southern Black Sea atmosphere, Atmospheric Research, 118, 153-169.

Tokgöz D.D.G. and Tuncel G. (2015), lonic composition of aerosols in northwestern Turkey, International Journal of Global Warming, 7(2), 161-172.

Tokgöz D.D.G. (2013), Temporal Variation in Aerosol Composition at Northwestern Turkey, Ph.D. Thesis, Middle East Technical University.

Zhang F., Cheng H.R., Wang Z.W., Lv X.P., Zhu Z.M., Zhang G. and Wang X.M. (2014), Fine particles (PM 2.5) at a CAWNET background site in Central China: Chemical compositions, seasonal variations and regional pollution events, Atmospheric Environment, 86, 193-202.

Zoller W.H., Gladney E.S. and Duce R.A. (1974), Atmospheric concentrations and sources of trace metals at the South Pole, Science, 183, 199-201. 